\title{
Caring for Xate, caring for Xateros: NGO monitoring, livelihoods, and plant-human relations in Uaxactún, Guatemala
}

\author{
Micha Rahder ${ }^{1}$ \\ University of California, Santa Cruz, USA
}

\begin{abstract}
In Uaxactún, a community forest concession inside Guatemala's Maya Biosphere Reserve, three species of xate palm, a non-timber forest product, are at the heart of quickly evolving webs of knowledge, identity, institutional alliances, and livelihoods. Xate palms are simultaneously the "daily beans" for the majority of Uaxactún residents, the object of intense study and regulation, a commodity marketable to international floral markets, a marker of local identity, and a ubiquitous part of the forest landscape. Now, as the result of a series of projects instituted by the conservation NGO, the Wildlife Conservation Society and other institutions, xate in Uaxactún is being transformed from a "natural", exploited part of the landscape to something to actively cuidar, or care for. NGO-driven dynamics of monitoring, study, and other external knowledge-making about the village are central to these ongoing shifts in xate-human relations, and to broader changes in local senses of place and identity. "Care" describes both material and affective relations, including practices and values that strive for a more liveable world without assuming an ultimate goal or a best solution. NGO projects that foster relations of care between villagers and xate palms are also a form of caring for villagers themselves, working as they do towards sustainable shared human/non-human futures. At the same time, however, these projects are "necessary but not sufficient" - caught in the problematic local scale, and failing to address deeper structural problems that keep Uaxactún residents dependent on precarious sources of income.
\end{abstract}

Keywords: Guatemala, Maya Biosphere Reserve, NTFPs, NGOs, environmental knowledge, care

\section{Résumé}

En Uaxactún, une concession forestière de communauté à l'intérieur de la Réserve de la biosphère maya du Guatemala, trois espèces de palmiers xate, un produit forestier non ligneux, sont au cœur de l'évolution rapide des connaissances, de l'identité, des alliances institutionnelles, et des moyens de subsistance. Les paumes xate sont simultanément les «haricots quotidiennes» pour la majorité des résidents Uaxactún, l'objet d'études approfondies et de la réglementation, un produit commercialisable sur les marchés internationaux floraux, un marqueur de l'identité locale, et une composante omniprésente du paysage forestier. Maintenant, à la suite d'une série de projets mis en place par l'ONG «Wildlife Conservation Society» et d'autres institutions, le xate d'Uaxactún se transforme à partir d'un partie du paysage exploitée mais «naturel», à quelque chose pour s'occuper activement. Conduit par les ONGs, surveillance et autres connaissances externes sur le villaje sont au cœur de ces changements en cours dans les relations xate-humain. Ils touchent aussi des changements plus larges sur des sens locaux de lieu et de l'identité. «Care» décrit les deux rapports matériels et affectifs, y compris les pratiques et les valeurs qui luttent pour un monde plus vivable, sans avoir l' objectif ultime ou une meilleure solution.Les projets de l'ONG que favoriser les relations de soins entre les villageois et les paumes de xate sont aussi une forme de prise en charge pour les villageois eux-mêmes. Ils travaillent vers un avenir durable qui sont non-humain/humain. Dans le même temps, ces projets sont «nécessaires mais pas suffisantes» - pris dans l'échelle locale problématique, ils ne traite pas les problèmes structurels plus profonds qui empêchent les résidents Uaxactún qui restent dépendants des sources de revenus précaires.

Mots-clés: le Guatemala, la Réserve de la biosphère maya, les PFNL, les ONG, la connaissance de l'environnement, les soins

\footnotetext{
1 Micha Rahder, PhD Candidate, Anthropology, University of California Santa Cruz, 1156 High Street, Santa Cruz, CA 95064, USA. E-mail: mrahder "at" ucsc.edu. This research was supported by a Doctoral Dissertation Research Improvement grant from the National Science Foundation, and a Dissertation Fieldwork Grant from the Wenner-Gren Foundation. Many thanks to WCS-Guatemala for their welcome and openness, and to the people of Uaxactún who tolerated the presence of one more researcher with aplomb. Thanks also to Josiah Heyman and anonymous reviewers for their help in improving the quality of the paper.
} 


\section{Resumen}

En la concesión forestal comunitaria de Uaxactún, localizada dentro de la Reserva de la Biosfera Maya en Guatemala, tres especies de palma Xate y otros productos forestales no maderables forman parte central de una compleja y cambiante red donde confluyen factores como la generación de conocimiento, la identidad, alianzas institucionales y formas de subsistencia. La palma de Xate representa al mismo tiempo "el pan diario" de la mayoría de los habitantes de Uaxactún; la palma es objeto de estudio y regulación, es una mercancía en el mercado internacional de flores, es también una parte central de la identidad local, además de ser un ubicuo elemento en el paisaje selvático. Sin embargo, en la actualidad y a través de proyectos de conservación que diversas instituciones como la Wildlife Conservation Society promueven, el Xate está siendo transformado, de ser algo "natural", que es explotado como un producto de la selva, a ser algo que activatmente hay que "cuidar". Estos cambios en las relaciones Xate-seres humanos, además de otras transformaciones como el cambio del sentido local sobre lugar e identidad, son resultado de las distintas dinámicas generadas por ONGs, como son las tareas de supervisión y monitoreo, la generación estudios y la producción desde afuera de conocimiento acerca de la comunidad. La idea de "cuidar" refiere relaciones materiales y afectivas, incluyendo prácticas y valores que buscan un mundo mejor pero sin que necesariamente conlleven la búsqueda de una meta última, o una transformación radical o de fondo. La promoción de relaciones de protección y cuidado entre pobladores locales y las palmas de Xate por parte de dichas ONGs, constituyen también formas de cuidado de los propios habitantes, ya que buscan la creación de un futuro común sustentable para los seres humanos y los no humanos. Sin embargo, estos esfuerzos promovidos por estas organizaciones son "importantes pero no suficientes" dado que dichos proyectos emergen en un contexto local de por si problemático, además de que no atienden problemas estructurales entre los que destacan por ejemplo, las precarias fuentes de ingresos de las que dependen los habitantes de Uaxactún.

Palabras Clave: Guatemala, Reserva de la Biosfera Maya, productos forestales no maderables, Organizaciones no gubernamentales, conocimiento ambiental, cuidado, conservación.

\section{Introduction}

Josue $^{2}$ paused as we hiked along the forest path and crouched down to carefully untwine a tightly wrapped tendril of climbing vine from a xate (pronounced SHA-tay) palm leaf, twisted and pulled by the vine's pernicious grip. "There are xateros (xate harvesters) who don't take these off", he said. "But, oooh! Pobrecita!" [Poor little thing!] he declared, delicately smoothing out the crumpled palm leaf. "When it rains it will become more beautiful", he assured me. Implied in this beauty was the leaf's recuperation into being harvestable, marketable, a potential source of income for xateros like himself, to be sold and shipped to the U.S. and Europe where the leaves are used in flower arrangements. Beyond a simple economic relation, however, his actions pointed to the ongoing transformation of xate in Josue's community, Uaxactún, from a "natural", exploited part of the landscape to something to actively cuidar, to care for.

Uaxactún (pronounced wah-shock-toon) is a village of approximately 1,000 people located inside Guatemala's Maya Biosphere Reserve, and has been granted a forest concession of over 320 square miles (829 $\mathrm{km}^{2}$ ), the largest community-managed forest in Central America. The Reserve - a patchwork of national parks, industrial and community forest concessions, and other protected areas - stretches over 8,300 square miles $\left(21,498 \mathrm{~km}^{2}\right)$, over twice the size of Yellowstone National Park in the western United States (Figure 1). Located in Guatemala's northernmost department, the Petén, the Reserve borders both Mexico and Belize, and many areas, particularly the western national parks, have been overrun with cattle ranchers, illegal loggers, agricultural migrants, and drug and human traffic heading north. Uaxactún, nestled in the heart of the Reserve's multiple use zone, has been relatively protected from such threats, and the village manages its concession for sustainable timber and non-timber harvesting, including xate palms.

The current transformation in Uaxactún residents' relationships with xate, the primary non-timber forest product (NTFP) harvested in the concession, is at the center of evolving webs of knowledge, identity, institutional alliances, and livelihoods. Xate palms - actually three distinct species with their own ecological and economic idiosyncrasies (see Box 1) — are simultaneously the "daily beans" for the vast majority of

${ }^{2}$ Individual's names have been replaced with pseudonyms throughout this article, with the exception of known public figures. 
Uaxactún residents, the object of intense study and regulation, a commodity marketable to international floral markets, a marker of local identity, and a ubiquitous part of the forest landscape. Between $60 \%$ and $80 \%$ of Uaxactún households rely on xate income at some point during the year, and the plant accounts for 30\% of total monetary income in the community (Zetina Tún 2011). Because of this extraordinary subsistence role, recent conservation and development projects designed to increase xate's local abundance in the forest understory are a rare example of convergent ecological and economic goals. NGO-driven practices of study and scientific curiosity, at the heart of these projects, are central to ongoing shifts in the relationship between xate and Uaxactuneros (village residents).

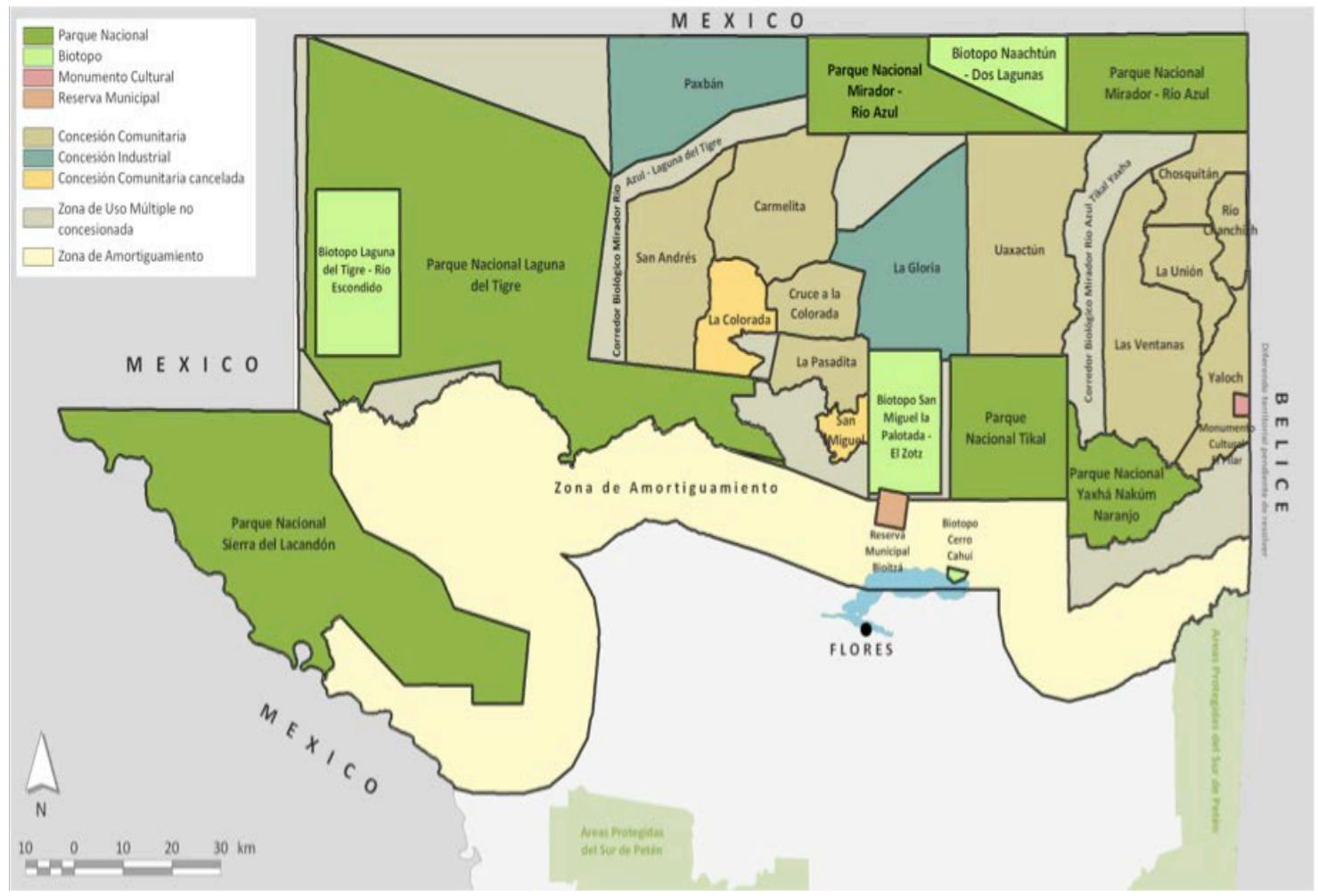

Figure 1: The Maya Biosphere Reserve, showing different administrative zones. Green and pink areas are "nuclear zones" (national parks, university-run biotope research zones, and municipal reserves); blue and brown are the "multiple use zone" (industrial and community-run forest concessions, respectively); and the yellow along the bottom is the "buffer zone." Uaxactún’s concession is located in the center of the multiple use zone, north of Tikal National Park. Source: CEMEC 2011.

In this article, I focus on the dynamics of monitoring, studying, and other knowledge-making practices of "outsider" individuals and institutions, and the role that these practices play in transforming local knowledge, livelihoods, and identity. This article is part of a larger research project on techno-scientific monitoring and mapping in the Maya Biosphere Reserve, for which the majority of research was carried out in state and NGO institutions - those creating, communicating, and using monitoring data, rather than those actors (human and otherwise) that are the subjects of monitoring. This article is the result of rounding out this "studying up" (Nader 1972) approach by seeking out the relationships between these institutions and their knowledge making practices with the people, plants, and issues being monitored, as well as the downstream effects of these practices and data, particularly once translated into conservation and development practice. This multi-sited research revealed the ways that multiple senses of time, space, place, and identity are co- 
constructed with official, centralized knowledge, and the case of Uaxactún and xate monitoring is exemplary of this broader dynamic.

Three species of xate palm (Chamaedorea spp.) are harvested in Uaxactún, known by the Spanish common names jade (jade, also called macho or male), hembra (female), and cola de pescado (fishtail). All three are understory plants, preferring dense shade, and grow in rich ecological interaction with several species of beetles and thrips (pollinators), as well as birds and mammals (seed dispersers). Once harvested, xate leaves can stay fresh for up to 4-6 weeks, making them an ideal product for international floral markets.

The market for jade (C. oblongata) persists year round, and the palm is found throughout the concession in high abundance. Hembra (․ elegans), too, grows abundantly in Uaxactún, but its market is concentrated in the dry season (February-May), with a surge around Easter. Seeds of both species are collected locally by xateros, and sold to OMYC for enrichment projects, taking 2-4 years to mature and produce seed. Jade harvested in Uaxactún is exported to the United States and Europe, while hembra is sold primarily to the Netherlands.

Cola de pescado ( $\underline{\text { C. ernesti-augustii) }}$ is by far the most valuable of the three species, with a yearround market. Very little of the palm is found in the concession; some people claim that fishtail has never grown in this area, while others report that it used to be abundant but was overharvested to near extinction. It is now being (re-)introduced into Uaxactún's forests by a municipal project: seeds are bought from dealers outside the community for Q300/lb (US\$38/lb, US\$84/kg), and the plants will take up to eight years to mature and produce seed.

Box 1: Xate palms.

The intensity of external monitoring and knowledge production in Uaxactún has become a mundane if not always uncontested - part of daily village life. These knowledges about but not of the village and its concession have become integral to local senses of place and identity, shifting and shaping ecological and subsistence practices. With this dynamic in mind, I focus on one international conservation organization in particular, the Wildlife Conservation Society (WCS), as it has been central in many recent xate projects, including formal studies, monitoring of extraction and marketability, understory enrichment, and others. WCS and its projects have been instrumental in turning Uaxactuneros relationship with xate from simple extraction into complex relations of care. The shifts described in this article are always partial - not total transformations, but rather complex, subtle, and often contradictory processes of change in both material and discursive relationships between villagers, plants, institutions, and the forested landscape.

I use the term care to describe particular relations - affective and practical, material and discursive both between Uaxactún's xateros and their palms, and between WCS (and other institutions) and Uaxactuneros. The term has been used with different definitions and theoretical orientations in a wide variety of literatures, most often in feminist analyses of feminine-gendered labor, especially childcare, healthcare, and education (Held 2006; Hochschild 1995; Mol 2008), or in discussions of welfare or development states (Williams 2001; Daly and Lewis 2000). Care has also appeared in the environmental context, particularly in ecofeminist work critiquing associations between 'caring' women and nature (Salleh 1993; MacGregor 2011; MacGregor 2004). In her critique of 'maternalistic' models of ecofeminism, MacGregor cautions that without a deeply considered de-coupling of care from women specifically, this concept can problematically reinscribe narrow definitions of women as political actors - as caregivers, rather than as citizens (MacGregor 2011). In the case of Uaxactún, however, it is men who are involved in the discursive and labor formations that I describe as 'caring', requiring a broadening of the term from these heavily gendered contexts of care.

Other feminist theory has taken up the idea of care in a much more general sense, describing it as involving both practice(s) and a particular disposition or set of values ( Held 2006; Tronto 1993). A good working definition is provided by Joan Tronto and Bernice Fisher:

On the most general level, we suggest that caring be viewed as a species activity that includes everything that we do to maintain, continue, and repair our 'world' so that we can live in it as well as possible. That world includes our bodies, our selves, and our environment, all of which we seek to interweave in a complex, life-sustaining web (Tronto 1993: 103; emphasis in original). 
Importantly, this definition is not restricted to care for humans, nor to actions by or on autonomous individuals, but rather recognizes care as fostering complex, distributed, ongoing relations of broad interdependence. I therefore also use care to decenter human exceptionalism in my analysis, and to emphasize that xate, too, is an active participant in these relations - what it likes and needs, how it grows, when it reproduces, all these affect emerging formations of labor, livelihoods, and identity in Uaxactún. In a similar usage, Mol et al. (2010) describe care as a particular logic or ethics that seeks to ameliorate, to make more livable, but without an assumed end goal of an ultimate best practice, cure, or solution. Instead, an ethics of care emphasizes that the question of the "good" is never settled, and always unfolds in particular contexts "...full of complex ambivalence and shifting tensions" (Mol et al. 2010: 14). Importantly, too, all of these definitions emphasize that practices and relations of care are never disembedded from complex intersecting sets of power relations, and that care is not an exclusive category - particular practices can simultaneously be caring and exploitative, instrumental, or oppressive.

It is this broad definition of care, with its recognition of ambiguity, contradiction, and complex relations, that I use to analyze shifting dynamics of NGO-community relations, NTFP harvesting practices, and livelihoods in Uaxactún. In particular, I emphasize an ecological notion of care, attending to the interplay of knowledge, power relations, and material interaction that shape the way care emerges at particular scales and relations, but not others. Political ecology has long drawn attention to conflicts between scales, particularly the 'local' scale of most conservation and development interventions and broader structural issues that greatly constrain the impacts of those projects (e.g. Bray and Anderson 2005; Brosius 1999; Escobar 1995; Ferguson 1990; Peluso 1995). This case study of xate in Uaxactún examines projects that attempt to enact multiple scales and types of care - of villagers for understory palms, of an NGO for local people, and of a community-NGO alliance for a forested landscape - revealing how these multiple forms of care can simultaneously support and undermine each other, particularly when considered within their broader political ecological contexts.

In particular, I explore whether NGO projects that foster care between villagers and palm plants might also care for the villagers themselves, as well as for the forest landscape. If care is a striving towards something better, without assuming that an ultimate goal or solution will be reached, then WCS's xate projects indeed fit the definition, working as they do towards sustainable shared human-non-human futures. However, the relations of power and knowledge within which these practices of care are embedded are deeply unequal, and small-scale xate projects fail to address deeper structural problems that keep Uaxactuneros relatively poor, marginalized, and reliant on precarious sources of income. As a result, the projects encourage the development of an environmentally caring subject - an environmentality (Agrawal 2005) - without a corresponding transformation in the multiple forms of political, economic, and ecological exploitation that underlie global NTFP markets. Bringing the concept of care into this political ecological analysis allows a recognition of efforts to ameliorate the situation of marginalized people and environments on multiple scales - striving towards an open-ended better, not a final good - while simultaneously recognizing the embedded contradictions and structural limitations to these efforts.

\section{The concession is the people: an introduction to Uaxactún}

Uaxactún refers to several things beyond the ancient Mayan site from which the name is borrowed ${ }^{3}$ : First, it is a village with a deep Petenero identity, tracing several generations in the Northern Petén department of Guatemala, contrasted with the larger population of recent migrants to the region. ${ }^{4}$ Second, it is a unidad de manejo (management unit), or a named area delineated in 1999 that covers 323 square miles (83,558 hectares) within the Maya Biosphere Reserve. Finally, it is a timber concession, assigning management and usufruct rights and responsibilities through a 25-year contract between the Guatemalan state

\footnotetext{
${ }^{3}$ The name was chosen by US archaeologist Sylvanus Morley in 1916 to refer to the Classic Mayan city next to which the current village sits. The words Waxac and Tun mean "eight stones" in Maya, but were also chosen because they sound like "Washington."

${ }^{4}$ Before the colonization boom of the 1970s, the Petén had an extremely low population density and only a few permanent settlements. Uaxactún was a center for the chicle (an NTFP) trade for much of its history, with the population (especially men) spending much of the year in forest camps, returning to the village during the off season or to transport NTFPs back to Uaxactún's airstrip for extraction.
} 
and the village non-profit Organización Manejo y Conservación de Uaxactún (OMYC, Management and Conservation Organization of Uaxactún). Of course, the distinctions between these three blur in practice, as one OMYC member's attempt to clarify made clear: "the unidad de manejo is just the area" he said, "the concession is the people." Echoing this equation of communal identity and contractual obligation, he informed me that a recent inquiry into the concession's benefits to the village simply didn't make sense: the concession is "a right", he insisted, too fundamental to the community's existence to ask about what benefits it brings.

Uaxactún's forest concession was one of twelve granted to local community organizations in the Maya Biosphere in the late 1990s and early 2000s, two of which were cancelled in 2010 due to repeated illegal activity and mismanagement. The concessions are located together with two industrial logging concessions and four delimited but un-contracted concessions in the Maya Biosphere Reserve's Multiple Use Zone, a key aspect of the UNESCO Biosphere Program intended to balance sustainable use and local livelihoods with biodiversity conservation. The concession is therefore part of a broad shift in global conservation during the late $20^{\text {th }}$ century towards community forest management, one which has been widely analyzed and critiqued in terms of its reconfigurations of politics, knowledge, subjectivity, and environmental and subsistence practices (e.g. Agrawal 2005; Pacheco et al. 2008; Sivaramakrishnan 2000; Zerner 1994).

Any village resident is free to join OMYC, and membership offers access to rotating temporary (up to one year) employment, and the ability to participate in concession management and policy decisions. Beyond the rotating positions provided by OMYC (cutting timber, working the saw mill, etc.), jobs are few in the jungle. The village is flanked by two well-excavated early Classic Mayan sites, and the surrounding landscape is rich with many more. This archaeological abundance provides seasonal work for men who are hired to dig and sweep away layers of history in the dry season, or occasionally for women hired as cooks for the archaeological camps. Still, most men in Uaxactún rely heavily on NTFP harvesting for subsistence income, and opportunities for women to earn money are exceedingly few. Only 18\% of adults had permanent paid employment in 2011, and a third of the community reports that xate, which can be harvested and sold year round, is their primary source of household income (Zetina Tún 2011).

OMYC and Uaxactún have been widely praised as an example of successful community forest management due to the concession's well-maintained forest cover (e.g. Gretzinger 1998; Nittler and Tschinkel 2005). However, these accolades elide the fact that the concession generated debt, rather than profit, for the community for many years, with poor financial management, oversight, and guidance. ${ }^{5}$ In addition, OMYC's leadership is challenged by a fractured, socially and politically diverse membership. It is a rule that members elect the OMYC board of directors every two years. In practice, however, each new board quickly takes the blame for any problems that arise in the concession, and have in recent history always been ousted long before their term is up. While concession jobs theoretically rotate through all OMYC members, in practice they go to those with friends - or at least, a lack of opponents - on the current board, further hastening the desire for overturning them among those left out. Factions split along old tender lines again and again, tearing apart the administrative structure from the "participatory" inside, but this tumult in OMYC leadership is perhaps a reflection of how truly democratic the organization is. Social and political divisions run like fault lines through the community, and the concession's institutional structures and ecological landscape are deeply entangled with this social world. After all, "the concession is the people," and Uaxactún's people are infamous among state and NGO staff (who otherwise extol the pleasures of working in Uaxactún's beautiful forest) for their social turmoil.

\section{WCS - an NGO at home in Uaxactún}

The Wildlife Conservation Society (WCS) has a long history of working in Uaxactún - in fact, the Guatemalan branch of this US-based conservation NGO started with a single short-term project in the village

\footnotetext{
${ }^{5}$ Early NGO inputs and accompaniment focused heavily on timber harvesting practices and infrastructural development, with financial and administrative decision making largely left up to inexperienced local administrators. The past few years have started to see a push back in the other direction, with a variety of institutions recognizing the necessity for administrative training and assistance, while also instituting a variety of neoliberal transparency and accountability measures that lean in similar directions.
} 
in 1996, and has slowly expanded to have much broader geographical and political influence. True to its origins, WCS-Guatemala has maintained a constant, if part-time, residential presence in the village over the years, building up from a single hut to a large multi-building compound shared with other institutions. Over the years, most of the houses that WCS built were burned down by villagers, expressions of complaint ranging from disapproval of specific projects to drunken revenge for loss of an NGO-paid job. Still, WCS has rebuilt every time, slowly replacing thatch-roofed huts with concrete and corrugated tin, less comfortable but distinctly less flammable than their forbears. This demonstration of commitment, staying even when angry individuals want them to leave, has built up a slow and steady trust between the NGO and many members of the village that other institutions fail to achieve.

If the concession is the people, WCS's current field program coordinator in Uaxactún, Juan Castellanos, is well suited to his position coordinating between the village and NGO. Juan - friendly, open, and outgoing - spends between $25-50 \%$ of his time living in the village, depending on the season and projects underway. The work in the village is "un rollo social", he tells me - tricky social business. ${ }^{6}$ Echoing the famous development critique of Mosse (2005), Juan told me that official measures of success and failure in his NGO projects didn't mean much: "Maybe at the end you get something that looks like 'good results,"' he said, "but [projects] won't actually do anything without the social aspect." Walking through the village, he greets nearly everybody he passes, calling out friendly hellos to a few and stopping to linger in conversation with most, keeping close tabs on daily happenings, concerns, and small-town gossip. Even when there is nothing much to say, there is a friendly presence to be made felt, an enduring human connection to be maintained with the institution.

Still, relations between WCS and villagers are never settled or conflict-free, especially given divisions within the community itself, and the broader context of the role of NGOs and the state in the Maya Biosphere Reserve. Characterized by historically weak state presence and programs, with many traditional state functions offloaded onto international and Guatemalan NGOs, the Reserve was characterized as an "NGO landscape" early in its history (Sundberg 1998), a reality which has changed little over time. Large international conservation NGOs like WCS have also been the subject of extensive critiques, particularly as institutions that impose the priorities of wealthy, Western donors over local concerns, and as part of neoliberal reconfigurations of environmental governance in which they are less locally accountable than the democratic states they are presumed to replace (Bebbington and Thiele 1993; Bray and Anderson 2005; Bryant 2002; Ribot and Larson 2005; West 2006). While these critiques are valid in many ways and contexts, WCSGuatemala now enjoys relative institutional autonomy from its New York-based global head office, and many projects and interventions in Uaxactún in particular have developed with collaboration and input from the community over time, rather than the cursory "participation" often featured in conservation and development projects (Cornwall 2006).

WCS is central to the shifting dynamics surrounding xate described in this article, and to other closely related transformations of knowledge, livelihood, and identity in Uaxactún. With its scientifically driven biodiversity conservation mission, the NGO is regularly involved in a wide variety of studies and monitoring activities in the village. This knowledge-production about Uaxactún goes hand in hand with WCS's long-term commitment to its residents and forest, and is an important part of the organization's ongoing work across the Reserve. The idea that outsiders, WCS in particular, know more (or know better) about the village and its landscape than villagers themselves - a common sentiment that privileges technoscience and formal education over local knowledges - has become incorporated into local senses of place, closely tied to Uaxactún's ecological practices and awareness. This connection between external knowledge-making practices and local identity follows recent work on place, in which places are considered to be constructed translocally, amid complex relations of power and meaning that are not geographically bounded even as they produce seemingly localized places (Gupta and Ferguson 1992; Massey 1994; Moore 2005; Tsing 2005). In Uaxactún, these translocal knots of knowledge, power, place, and identity are being constructed through evolving relations between villagers, the state, NGOs, and other researchers (including myself), and the landscape and its many non-human inhabitants. In particular, knowledge about Uaxactún - even when largely unavailable to residents

${ }^{6}$ The Spanish term rollo carries rich connotations that are difficult to translate. In this context, it directly means "business" or "matter", but also calls up something complicated, messy, or difficult to navigate. 
- is driving transformations in senses of place, identity, and many other aspects of local life, including the practices of harvesting, marketing, and caring for xate palms.

\section{Caring for xate...}

On the day he took me harvesting, Josue showed me how to collect xate according to the rules of OMYC's sustainable management plan, leaving at least two full-grown healthy leaves, or one plus a shoot of new growth (called a candela, or candlestick), to ensure the survival and flourishing of the plant. But he also cared for plants that he wasn't harvesting as he moved through the underbrush: removing diseased or insectridden leaves, or patiently disentangling the palms from aggressive vines. Josue is a xatero, a forest labor identity that builds on histories of harvesting other NTFPs in Uaxactún, particularly chicle, the natural rubber used in chewing gum before the invention of synthetics. Many Uaxactún residents still refer to themselves as chicleros (chicle harvesters), even though the market for chicle dropped enormously in the 1960s, due to political upheaval in Guatemala and the invention of synthetic gum alternatives.

Xate has since replaced chicle at the heart of Uaxactún's forest livelihoods, and now stands as a symbol of regional histories of extraction in which it never really took part. ${ }^{7}$ Other NTFPs are still harvested in the concession, including chicle (Manilkara zapota), allspice (Pimenta dioica), ramón nut (Brosimum alicastrum, sometimes sold as "rainforest nut" in English), and others. But xate has thoroughly permeated the village as a symbol of local identity, even forming the basis for a costume in the village's annual Independence Day pageant. One member of OMYC's board of directors referred to xate harvesting as an "actividad de nuestros abuelos" [activity of our grandfathers], while another told me that xate had always been "everywhere", but until recently was just one more plant on the landscape, completely without economic value. The latter version is perhaps more accurate historically, but the imaginative memory of xate-cutting abuelos reflects current intersections of local identity and forest livelihoods. By connecting xate with old chiclero histories, the palm is tied to a deeper sense of identity and tradition based on living and working in the forest.

\section{Learning to care}

The material and discursive underpinnings of xatero identity are shifting, and not just from one NTFP

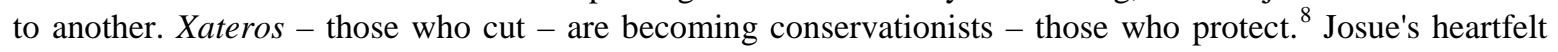
reactions and care for xate as he collected leaves is one example of this shift, an affective connection shaped by a recent six-month job with WCS in Uaxactún. These WCS jobs rotate through OMYC members, and include daily care for xate in nurseries around the NGOs housing compound in the village, and in plantations beneath the concession's forest canopy. Uaxactuneros hired by WCS learn to talk about "what the plants like", and are trained to be mindful in their work with the seeds and seedlings. This manifests in many details: xate seeds are neatly arranged in furrowed rows of soil (a strong contrast with the irregular sowing of crops in traditional swidden agricultural plots ${ }^{9}$ ), watering pipes over seed beds are patiently watched and manually rotated so that water falls evenly across them, thatch roofs over the nurseries are tended to mimic the shade of the forest, and watering is adjusted to seasonal patterns of heat and humidity - not to replicate natural conditions, but to encourage the palms to survive and mature more quickly.

These micropractices of care are part of recent projects to increase the abundance of xate in Uaxactún's forests, established through a formal Acuerdo de Conservación (conservation agreement) with WCS, supported by Conservation International (CI) and other donors. ${ }^{10}$ These projects grow palm seedlings, then

\footnotetext{
${ }^{7}$ For more on Petenero and chiclero identity, see Schwartz's (1990) social history of the Petén, forest labor, and identity.

${ }^{8}$ Of course, not all harvesting practices were previously purely destructive, and indeed historic chiclero practices of leaving chicle-producing trees to recover for several years between rubber extractions is often cited as proof of a longstanding "sustainability" or "conservationist" ethic among Uaxactuneros and Peteneros more broadly, though these practices were not understood in these terms at the time.

9 This by no means indicates that swidden agriculture is not a form of caring for crops, that it is ecologically unsustainable, or otherwise inferior to xate care practices. I merely intend to draw attention to the contrast in seed sowing practices, which form part of new relations with xate in particular.

${ }^{10}$ Uaxactún was the first community in the Maya Biosphere Reserve to sign an Acuerdo, part of an international CI-led program that is slowly spreading, via partnership with WCS, across the Reserve. The Acuerdo was signed in 2009 by the
} 
transplant them to areas of the concession designated for NTFP harvest, enriching the natural abundance of a common resource. It is in the nurseries associated with this project that new relations to xate are being formed. Hired Uaxactuneros must learn to recognize the needs of the plants with great sensitivity (sun damage, insect infestation, etc), and become familiar with the different growth and reproduction rates of the three species. The three men who rotated through the WCS positions during my fieldwork — all of whom usually rely on xate harvesting as their primary source of income - spoke with great pleasure about how much they had learned about xate, identifying this new knowledge as their favorite part of the job, and demonstrating a real tenderness in their interactions with the plants.

\section{Monitoring and transformation}

The move to increase xate's local abundance and to institute sustainable harvesting practices was triggered by the rise of external monitoring practices that came along with Uaxactún's concession contract in 2000. In the concession's early years, all xate was sold to external contractors by weight, encouraging xateros to simply cut as much as they could - including damaged or diseased leaves - to earn money. ${ }^{11}$ A 2004 WCS study of the quality of harvested xate (defined as the marketable percentage of harvested leaves) estimated that only $25-30 \%$ of leaves sent to contractors were being selected for market. Concerned with overharvesting and poor economic returns from this system, a xate selection facility was established in Uaxactún, operated by OMYC with NGO assistance. The concession now pays per marketable leaf instead of by weight, doubling the price per leaf paid to harvesters, allowing more oversight and control within the concession, and capturing a larger proportion of xate's economic benefits within the community by cutting out contractors and selling directly to exporters in Guatemala City (OMYC 2009). In addition, women from the village are hired for sorting and selection of harvested palm leaves, adding a frequently touted benefit to local women to the project.

When the selection facility was introduced, WCS conducted another study of the ecological impacts of xate harvesting practices, determining how many leaves could be cut from a plant without killing it, and OMYC developed a xate management plan based on this information. These days, actual cutting is not surveyed in the field; instead, the continued monitoring of xate quality in the selection facility has became a proxy measure for sustainable harvesting practices - less waste at the market selection point indicates less careless overharvesting in the forest. Each individual xatero now has their quality statistics reported back to them as an assessment of their harvesting practices. Similarly, the total percentage of xate selected for market is calculated by WCS, and then reported back to the concession by graph as a measure of their ecological management success (see Figure 2). Since this monitoring began, the percentage of leaves selected for market has remained well above the 70\% minimum set by OMYC's management plan, and in 2011 stayed consistently above $90 \%$.

A poster-sized copy of the xate graph hangs in the selection facility. WCS posted it to communicate monitoring results to xateros and selectors. However, reading graphs requires specialized visual and numerical literacy, and this one was not well designed for communication to a non-expert audience. In fact, the graph is hard to interpret even for those familiar with the visual medium (look, for example, at the inconsistent timescale on the bottom, ${ }^{12}$ the unexplained line at $70 \%$, etc.), and for those unfamiliar with reading scientific figures it is nearly impenetrable. For people working in the selection facility, the graph is usually interpreted simply as a reminder that somebody is watching to make sure they're not screwing up. In my visits to the facility, I never once saw anybody glance at the graph without my prompting, until the day a USAID delegation visited and gathered around it to see the impacts of their funding, at which point the graph very successfully communicated responsibility, collaboration, and sustainability to an important donor.

village's Community Development Council, OMYC, WCS, CI, and the National Protected Areas Council (CONAP), after approval by majority vote in an open community assembly.

${ }^{11}$ NTFP extraction by locals sold to extra-local contractors was the dominant form of labor organization in the Petén throughout most of the $19^{\text {th }}$ and $20^{\text {th }}$ centuries (Schwartz 1990).

12 The year 2009 is entirely absent from this graph due to a lack of funding for ecological monitoring in WCS that year. Previous monitoring was funded through the WCS Living Landscapes program, and beginning in 2010, funds for this activity were guaranteed by their inclusion in the Acuerdo de Conservación. 


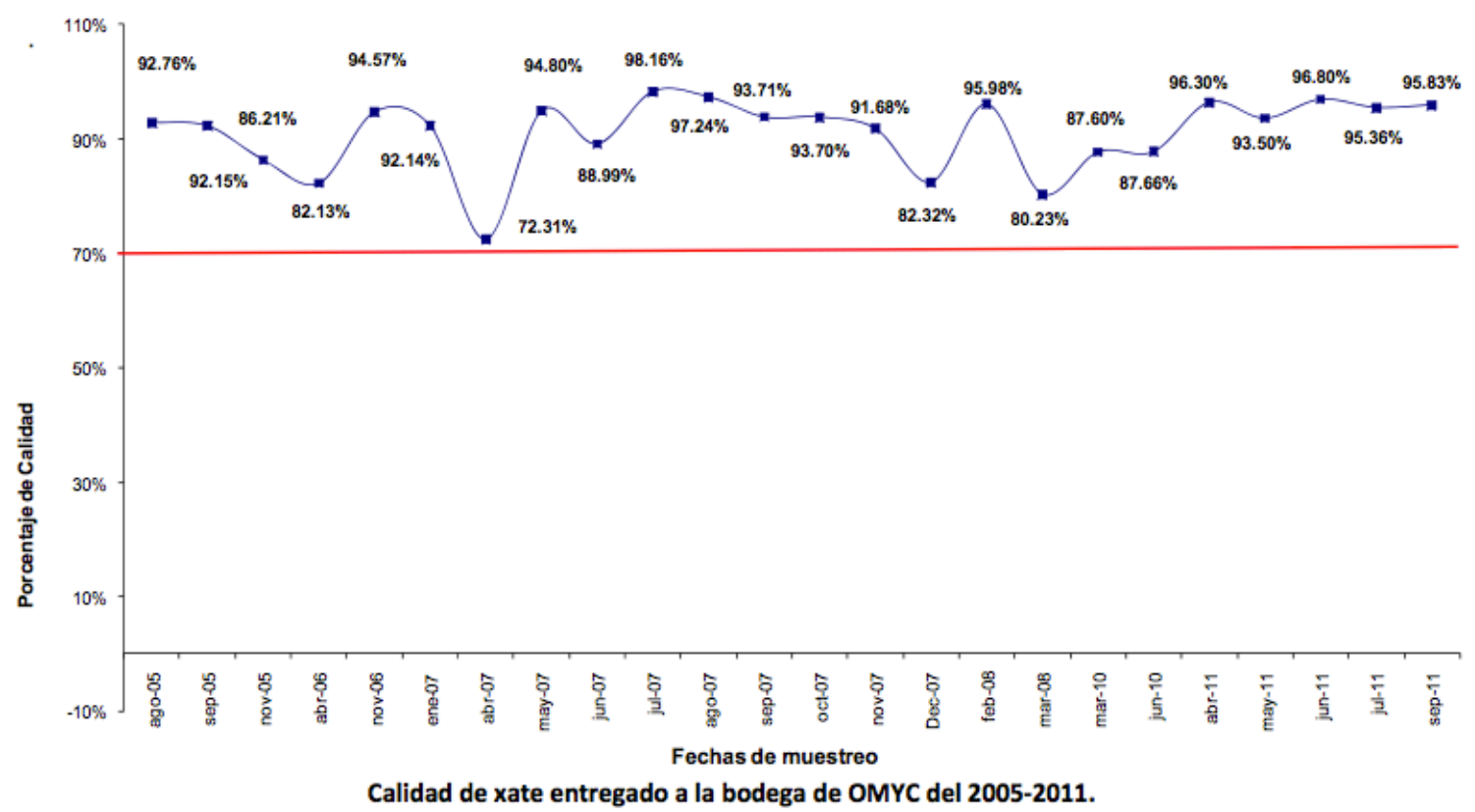

Figure 2: Quality of xate brought to the OMYC selection facility from 2005-2011. Source: WCS 2011.

\section{A known place - external study and sense of place}

Surveys, studies, and observation like those mentioned above are a constant, mundane part of village life, ranging from xate quality monitoring to detailed ethnographic examinations of the community's dense social world, and broad ecological and archaeological views of the surrounding landscape. At one point during my fieldwork, there were five different surveys circulating in the community, including one for which I was involved with as an NGO volunteer. But even before I showed up at their doorsteps asking for household characteristics, villagers easily identified me as a researcher (not a tourist) because I had stayed for more than a single day. Children called me by the names of other gringa graduate students who had worked there before, while their parents reminisced pointedly about the gifts those visitors had left. This is a wellstudied place, and the knowledge made in and about Uaxactún is fundamental not just to the way that the village enters regional, national, and global conversations, but also to the construction of the village and surrounding forest as a local, knowable place.

For the most part, the findings of these studies are directed outwards and upwards, to international academic and professional audiences, to NGO donors or granting agencies, or simply into state and NGO project files. Most results never find their way back to the village; I suggested to my surveying partner that we present our eventual results to a village assembly, but although he liked this idea, we never made it happen. Many villagers expressed frustration with this dynamic, asking, what good do these studies do us? Moving from house to house, I carried my ethnographer self alongside my NGO surveyor role, inviting respondents to ask me questions as well, or to discuss survey items as we went. The most frequent response to this invitation reflected exasperation with the intensely studied nature of life in the village. People asked: What is this survey for? Who will see the results, will we? What happens if the results don't look good for the project?

Of course, much of the knowledge generated by these surveys, while never formally reported back to villagers, is already familiar to them in intimate detail. For example, one of the concurrent surveys enrolled kids aged 13-16 from the village school to carry out the door-to-door work, teaching them basic research methodology while providing assistance for the NGO conducting the study. The kids were instructed in the proper way to politely approach a home and ask questions, but also reminded not to bother asking questions if they already knew the answer. The teacher prompted: it wouldn't be nice to ask a family whether they have 
electricity if you know they don't, and we all know which houses do and which don't. ${ }^{13}$ "What about Doña Anna?" he asked as illustration, "her house by the entrance to the ruins, does it have electricity?" "Yeeeess," answered the chorus of teenage voices. Right, he responded, so you wouldn't have to ask. You don't want to be rude and leave people with a bad feeling about surveys, the teacher concluded, because there will always be more.

Several villagers also recognized that those doing the surveys often brought other benefits along with them, and might return to the community in other capacities. One man pointed out that Roan Balas McNab, the American director of WCS-Guatemala, first came to Uaxactún for his Master's research, and then stayed the origin of one of the most influential NGOs in the Reserve today. At least three others who originally came to conduct a study have returned to work in the village on behalf of NGOs. Foreign researchers like myself often choose Uaxactún as a research site due to its relative accessibility, safety, and the availability of institutional introductions to key people in the village; I even crossed paths with two other U.S. graduate students there. While the implications of our academic studies may be even father removed from daily village life than those of NGOs, our presence fuels small-scale local economies and a sense of connection to global ideas, markets, and worlds otherwise inaccessible.

This sense of connection is also a sense of place. Through the experience of being the objects of constant study, Uaxactuneros come to know their place as one defined by its standing forests and the "clean air" they produce (a local interpretation of global climate discourse), its lauded example of community-based management, and its carefully cultivated cultura de conservación (culture of conservation), a phrase deeply reminiscent of Agrawal's environmentality (Agrawal 2005), heard often in the local school, community assemblies and meetings, and documents, reports, and presentations about the community. These priorities of identity and place are constructed in interaction with outsider institutions and individuals, and in many ways villagers adopt these along with the sense that others know their place better than they themselves. One survey respondent told me - without noticeable irony - that WCS had more information about the community and concession than OMYC, such that now when they want to know something about themselves, they go to the NGO to ask. Authoritative knowledge about this place was increasingly recognized as extra-local, while some of the most valuable local knowledge included the ability to access and navigate external discourses, institutions, and resources. ${ }^{14}$

Rather than a sense of knowing, then, a sense of being known shapes how villagers understand their own and others' place in the forest - including the place of xate palms. External monitoring has been central to the transformation of economic and ecological relations between Uaxactún residents and xate palms, beginning with WCS's study of extraction in the early 2000s. These initial short-term studies developed into the long-term monitoring of xate quality that continues to this day, as well as driving projects to increase its abundance in concession forests through nurseries and understory enrichment plantings. These projects emphasize the needs and protection of the plants, but in so doing also address needs of the local population who rely so heavily on xate for subsistence. At the same time, the long-term nature of these monitoring commitments is changing the way that WCS communicates and engages resulting knowledge in the community.

\section{Reporting back}

Despite its local illegibility, the graph hanging in the selection facility forms an important part of WCS's new initiative to report monitoring data back to community-managed forest concessions throughout the Maya Biosphere Reserve, a strong contrast to the many other studies that simply extract information. The year 2011 marked the first year of this reporting, with formal presentations and electronic and hard copy summaries of findings presented to the leaders of several community concessions, including OMYC's board of directors. Uaxactún's presentation was highly congratulatory and full of lively discussion, with frequent

\footnotetext{
${ }^{13}$ There is no electric grid in Uaxactún, but some houses have gasoline-powered generators or a rooftop solar panel.

${ }^{14}$ I do not mean to imply that there is no "local knowledge", ecological or otherwise, but rather that there is a common sentiment that authoritative statements about the village and its forest, those recognized to be true by broader audiences, must refer to or be based on these external monitoring data. In practice, much of what is eventually recognized as official, external knowledge has actually been passed to the institutions through informal interaction with villagers.
} 
questions from OMYC board members and comments provided by Juan Castellanos, who acted in a kind of translator capacity, providing local context and explanation for the data projected on screen. For example, when looking at a map of satellite-detected fires, Juan pointed out that all the fires were well within the limits of the designated agricultural area of the concession (controlled burns are part of local agricultural practices), and that although they registered as burnt bosque (forest) according to satellites and technical definition, locals would recognize the burned lands as guamil (regrown fallow), not as mature forest. ${ }^{15}$

Juan's guiding commentary also reflected his subtle awareness of the gap between NGO lingo and local ways of speaking. Once, he recounted to me, he had seen a poster in Uaxactún discussing "tools for sustainable development," but people did not seem to understand what it was about. He asked a few men what they understood by the word tools and they answered: hammers, screwdrivers, saws. He made clear that the issue was not with literacy per se, but with the ways that language shifts between formal institutional and rural contexts - an issue that echoed back to me when viewing the xate quality graph in the selection facility. Still, even basic efforts to report back to the concession set WCS's xate quality and other ecological monitoring apart from most studies.

In the case of xate, monitoring and reporting back have played a pivotal role in the transformation of institutional, labor, and ecological relationships. Even without a fine-grained understanding of the xate graph, its presence in the selection facility communicates the presence of external oversight, and the supportive message that the concession is successfully managing the ecological sustainability of key forest species. And this reporting-back also serves the NGO. One WCS biologist emphasized the importance of external evaluation for the concession, and the interdependency between WCS's monitoring program and OMYC, formalized in the Conservation Agreement. Through this exchange, OMYC gains measures and reports of their ecological success that have high reliability and rigor, as marked by coming from external sources. On the other side, WCS can say that their monitoring programs serve an important purpose for local people, justifying further funding for future monitoring of the landscape.

\section{5. ...Caring for Xateros?}

External monitoring practices are found at the heart of new formations of caring for plants, caring for the landscape, and caring for people. These knowledge-making practices, and the projects attached to them, continue to transform xateros' relationships to the forest landscape and the plants within it, shifting these from pure extraction to more complex interactions characterized by curiosity, nourishing, and care. WCS's xate projects - from germinating, raising, and transplanting seedlings to careful harvesting, selection, and monitoring of marketable leaves - have changed the plant from a natural part of the landscape into something that is actively cultivated and cared for. At the same time, they are changing xateros from ecologically destructive bulk harvesters to careful conservationists. Most xateros have not yet worked in WCS's nurseries, but as people rotate slowly through these jobs and interact with different kinds of monitoring and attention, they emerge with transformed perspectives and affective connections to the plant, its place in the landscape, and shared human-xate futures.

\section{Care is not a panacea}

As much as these transformations are hopeful in many ways, the focus on increasing the abundance of xate leaves many problems unaddressed. A large proportion of Uaxactuneros rely on xate for basic subsistence - their daily beans - and when I expressed my hopefulness about these projects as a way of caring for people by way of caring for the plants and landscape, Juan Castellanos brought me back down to earth. "Maybe..." he hesitated, "No, maybe not. In the question of food security, no. It wouldn't cover it. It wouldn't guarantee enough income." Similarly, when Josue spoke to me of his pleasure in learning about xate in WCS's nurseries, he emphasized his changed perspective, but also pointed to the limits of this knowledge:

\footnotetext{
${ }^{15}$ Forests are defined by the Reserve's Center for Ecological Monitoring and Evaluation as 30\% or more canopy cover and a minimum $5 \mathrm{~m}$ height.
} 
Before working here, I didn't know anything about xate - how to grow it, how to... nothing. But thank god, I learned, I learned. Not just to cut. Not just to destroy. Because to be a xatero is to destroy. But I'm not saying... Maybe you have a huge need, and if you find a little plant of xate that just has one leaf, you just have to cut it, out of necessity. And then that little plant is going to die.

For Josue, the need to earn enough to support one's family trumped discourses of sustainability and the individual relations of care that he has cultivated with xate plants.

This transformation of perspective, then, might be read as a form of environmentality, of making new environmental subjects (Agrawal 2005), but without transforming the broader conditions of life and labor in the Reserve. As much as caring for xate may be transforming perspectives and relations, and will almost certainly help ensure access to the resource in the future, it does not change the basic structure of work that requires men to work as independent laborers, trekking through the forest to cut and haul palm in large bundles loaded onto mules, motorcycles, bicycles and strong backs. The advantage, another Uaxactunero told me, is that whenever you have a free day, you can go out and work, and you'll see the money quickly. But, he continued, in the summer it's unbearably hot, and in the rainy season the paths are nearly impassable with mud. It's difficult physical work, entirely dependent on uncertain international markets, and work that is heavily gendered. ${ }^{16}$

What of hose women who were hired to work in the selection facility? Their work involves mostly sitting around unpaid, waiting for xateros to arrive in the afternoon with bundles of palm, at which point they work in short, ten minute bursts of sorting. The women separate marketable from damaged, too small, or discolored leaves, then report the totals to both the xatero and the facility supervisor, who records them in a monitoring log. The selectors, like xateros, are paid by the leaf, and on a good day they might earn between 25 and 30 Quetzals (US\$3-4), compared to the 600 to 800 Quetzals (US\$75-100) that a xatero can earn in the same day. Even the packers - also men - who work alongside the selection women, trimming and rolling up bundles of xate after they have been sorted, are paid more than twice as much per leaf. The women's work is by no means hard, and there are few other opportunities for paid employment for women, but to sell these meager earnings as a great gender-equality benefit is hard to swallow.

And while the possibility of earning over US\$75 for a hard day's work can seem like an extraordinary opportunity in a place otherwise devoid of income sources, the precarity of this income - especially considering factors like global markets or external support - should not be underestimated. While the global commodity chain into which xate is sold currently operates in a regular, structured way in Uaxactún (OMYC has contracts with mid-level distributors who transport the palms by truck to Guatemala City, at which point they are flown around the world), the overall structure of this supply chain and the U.S. and European floral decoration markets upon which it relies are inherently unstable and precarious. There are many points of vulnerability along this chain, and a change in any one could undermine this vital source of income for Uaxactuneros - for example, there have been increasing attempts to start xate plantations in other regions of Guatemala, where the palm is grown under artificial shade to replicate the forests of the Petén; if these become successful, they may undermine Uaxactún's xate sales through direct competition or via ecological claims to provide the plant without harm to protected forests.

Most significantly, the future consumer market for the palms is unpredictable in terms of potential shifts in valuation or demand. Chicle, the former heart of Uaxactún's economic activity, is instructive in this regard: extraction of this single resource deeply influenced the social and ecological formations of the entire Petén region for centuries, but a sudden drop in market demand in the 1970s collapsed most of these formations (Schwartz 1990). Xate may have replaced this natural rubber in local forest labor identities (xateros instead of chicleros), but the regional system in which this older form of extraction took place has also disappeared. Now, the individualized risk and reward of NTFP extractive labor are not longer an exception on the global scene, but are a part of the constitutive combination of "self-exploitation" and "superexploitation" that drive global supply chain capitalism (Tsing 2009). Combined with these changes in

${ }^{16}$ People say that there used to be xateras (female harvesters), but nobody could tell me exactly when or why women stopped harvesting xate, nor think of any woman currently living in the community who ever cut xate. 
global political economic structures, the declaration of the Maya Biosphere Reserve in 1990 shifted state and NGO priorities in the region towards conservation, a position fundamentally at odds with extractive economies.

Uaxactún's geographic marginality places it at an advantage in terms of these new regional priorities to preserve forest cover - protected as it is by poor road access and the buffering effects of Tikal National Park but at the same time this reduces the possibility of improved access to basic goods and services. The village still lacks reliable drinking water, electricity, or communication infrastructure, all of which are tightly constrained by regulations governing protected areas. Uaxactún's concession is more than halfway through its 25-year contract with the state, and despite recent praise for its forest management practices, the threat of losing concession rights, or even being evicted from the area, is strongly feared within the community (Zetina Tún 2011). OMYC documents also point to a lack of political or legal security with changing national governments; lack of political will on the part of various state agencies to uphold their end of the concession contract; neoliberal trade agreements that undermine local rights; lack of market regulation for many of the forest products produced; petroleum interests; and other serious threats to the concession (OMYC 2009). At multiple interlocking scales, vulnerability and precarity dominate.

Temporary solutions and improvements, including the xate enrichment and extraction activities detailed here, are deeply subsidized (as well as supported in non-economic ways) by NGO projects, which are themselves constrained by short term funding cycles and global institutional priorities that may have little to do with local needs. While the Guatemalan branch of WCS enjoys considerable programmatic freedom from its global head office in New York City, the contradictions between the organization's driving biodiversity conservation mandate and efforts to integrate local social, political, and economic concerns are many - WCS is, after all, a biodiversity conservation organization first and foremost, despite its local engagements. These contradictions are well documented in the literature (e.g. Chapin 2004; Bray and Anderson 2005; West 2006; and in the Maya Biosphere Reserve, Sundberg 1998). Even at the level of maintaining its daily operations and institutional structure, WCS must prioritize extensive studies, project writing, assessment and reporting activities, and other work that has little to do with local people. The uneven dynamics of knowledge production, and the recognition that "reporting back" to local actors is also a generative activity for future NGO funding, are exemplary in this regard. These contradictions are deeply familiar to those working in WCS and other NGOs, but recognition of these limitations is not the same thing as transformation. At the scale of WCS presence in Uaxactún, Juan Castellano's recognition of the difference between official project "success" (valuable to the institution and its donors) and actual positive outcomes on the ground begins to ameliorate this tension, especially since this recognition shapes his work and decisions in the village. But this itself is a precarious, tenuous intervention, reliant on the social skills and political judgments of a single individual who is ultimately unable to change the power relations in which he too is embedded.

Overall then, these xate projects, and the integrated conservation and development framework within which they fit, might best be described by the phrase used by Donna Haraway in her description of complex care in interspecies relations: they are necessary, but not sufficient (Haraway 2008). While the projects do run in parallel with a strong emphasis on education initiatives aimed at getting kids out of Uaxactún and forest labor in the future, they are ultimately more concerned with the permanence and well-being of the plants than the people. The collaborations between WCS and OMYC centered around xate are part of an important and transformative project, but to truly transform the future of both Uaxactún's forest and people, new forms of care, labor, and politics need to engage as deeply with human needs as they do with the needs of key forest species.

\section{Conclusion}

As Uaxactuneros come into contact with the nurseries, enrichment projects, and ecological monitoring initiatives of WCS and other institutions, their relationships to xate palms are changing in affective and practical ways. Ten years ago, xate was simply a ubiquitous part of the local forest understory, to be collected and sold with no regard to future abundance, and certainly without care for the fate of individual palms. Now, the plant is no longer simply cut and sold, but also sprouted, watered, transplanted, and harvested with new attention to the palms' future health. Along with these transformations in harvest practice come changes in local sense of place and identity - no longer just laborers pulling their livelihoods from the endless forests of 
Petén, Uaxactuneros now extol their "culture of conservation", and figure themselves not just as extractors, but also as protectors. These shifting material and discursive relationships to understory plants and the forested landscape they grow on are tied to deep local histories of NTFP labor, and are always partial and contradictory - fostering complex relations of care even as they rely on a continued definition of xate as an exploitable commodity.

These shifts are being driven in large part by the dynamics of external monitoring and study, part of a broader dynamic of knowledge-extraction that shapes Uaxactuneros' understandings of who they are and where they live. Rather than being a strict contrast between "local" and "external" knowledges, studies about Uaxactún - its people or its plants - are always constructed out of the relations between villagers and institutions or researchers, with "official" or "scientific" knowledge relying heavily on local experiences and stories (and only sometimes recognizing this fact). More important than the content of any one study, however, is the way in which this constant monitoring reinforces the village's place in regional institutional and global environmental orders, and brings into daily relief its marginality in networks of capital, knowledge, and meaning. Although xate quality monitoring is based on a strange calculation in which marketability stands in for ecologically sustainable field harvesting practices, its implementation and ongoing presence in the village has been key to transforming local plant-human relations.

WCS, like many biodiversity conservation NGOs, has come to incorporate human development projects, like health and education initiatives, into its environmental programs. In many ways, the organization's xate projects in Uaxactún are a stellar example of the successful integration of these two goals: by improving the wellbeing and abundance of an important part of the forest understory, the projects also guarantee the future presence of a resource essential for local subsistence income. As such, the projects are indeed both caring for xate, and caring for xateros - with care indicating a set of provisional, often contradictory practices and values, intended to foster complex and ongoing interrelations, and without an assumed ultimate goal or solution to current problems. Given this provisional nature, however, sometimes care is not enough.

The working out of shifting, best-case strategies to ameliorate local livelihood conditions is an essential function of short-term conservation and development projects, but these projects fail to address deeper structural issues that keep Uaxactún and its residents in a tenuous position, patching together livelihoods from a variety of self-driven, labor-intensive, and irregular sources. Its economic and social marginalization have broad impacts on the community, which suffers high rates of violence, drug and alcohol abuse, and poor access to health services. It is not necessarily the job of conservation NGOs to address these concerns - institutions which face their own structural and political constraints - but even if Uaxactuneros develop deeply caring relations with the forest and fundamentally conservationist local identities, the practical effects of these transformations will be limited by the basic need to feed one's family.

As such, it is essential to consider care ecologically - that is, at multiple scales and embedded within complex and contradictory relations of power. By attending to the interplay of knowledge, power, and material practice at multiple scales - by thinking care within a political ecological framework (Gezon and Paulson 2005) - it becomes possible to see the ways in which care emerges at particular scales and relations, but not others. Care makes it more possible to live in the absence of fundamental changes in the political, social, ecological, and economic marginality of Uaxactún (and similar places), but it is this exact same extension of possibility that means care is never enough. Conversely, close attention to the material practices and embedded values of care is useful for not disregarding these and other conservation and development projects as simple extensions of the broader structural status quo. Care is a striving, a concerted movement towards something a little bit better, if not an ultimate good. Like Josue's affectionate attention to the health of wild xate palms and ultimate prioritization of his family's food security, the contradictions of conservation and development contexts are inescapable. And like Josue does, finding ways to care even when faced with these contradictions is an essential form of striving, a striving mirrored by WCS in its projects even as it is undermined by the many other external political and economic forces shaping life, livelihoods, and ecologies in Uaxactún. 


\section{References}

Agrawal, A. 2005. Environmentality: technologies of government and the making of subjects. Durham: Duke University Press.

Bebbington, A. and G. Thiele. 1993. Non-governmental organizations and the state in Latin America: Rethinking roles in sustainable agricultural development. New York: Routledge.

Bray, D.B., and A.B. Anderson. 2005. Global conservation non-governmental organizations and local communities. Working Paper 1, Conservation and Development Series. Institute for Sustainability Science in Latin America and the Caribbean, Florida International University.

Brosius, J.P. 1999. Green dots, pink hearts: displacing politics from the Malaysian rain forest. American Anthropologist 101(1): 36-57.

Bryant, R. 2002. Non-governmental organizations and governmentality: 'consuming' biodiversity and indigenous people in the Philippines. Political Studies 50: 268-292.

Chapin, M. 2004. A challenge to conservationists. World Watch Magazine 17(6): 17-32.

Cornwall, A. 2006. Historical perspectives on participation in development. Commonwealth and Comparative Politics 44(1): 62-83.

Daly, M., and J. Lewis. 2000. The concept of social care and the analysis of contemporary welfare states. The British Journal of Sociology 51(2): 281-298.

Escobar, A. 1995. Encountering development: the making and unmaking of the Third World. Princeton: Princeton University Press.

Ferguson, J. 1990. The anti-politics machine: "development," depoliticization, and bureaucratic power in Lesotho. New York: Cambridge University Press.

Gezon, L.L. and S. Paulson. 2005. Place, power, difference: multiscale research at the dawn of the twentyfirst century. In S. Paulson and L.L. Gezon (eds.) Political ecology across spaces, scales, and social groups. New Brunswick: Rutgers University Press. Pp1-16.

Gretzinger, S. 1998. Community forest concessions: an economic alternative for the Maya Biosphere Reserve in the Peten, Guatemala. In R. Primack, D. Bray, H.A. Galletti, and I. Ponciano (eds.) Timber, tourists, and temples: conservation and development in the Maya Forest of Belize, Guatemala, and Mexico. Washington, D.C.: Island Press. Pp111-124.

Gupta, A., and J. Ferguson. 1992. Beyond "culture": space, identity, and the politics of difference. Cultural Anthropology 7(1): 6-23.

Haraway, D. 2008. When species meet. Minneapolis: University of Minnesota Press.

Held, V. 2006. The ethics of care: personal, political, and global. London: Oxford University Press.

Hochschild, A.R. 1995. The culture of politics: traditional, postmodern, cold-modern, and warm-modern ideals of care. Social Politics: International Studies in Gender, State and Society 2(3): 331-346.

MacGregor, S. 2004. From care to citizenship: calling ecofeminism back to politics. Ethics and the Environment 9(1): 56-84.

MacGregor, S. 2011. Beyond mothering earth: ecological citizenship and the politics of care. Vancouver: University of British Columbia Press.

Massey, D. 1994. Space, place and gender. Cambridge: Polity Press.

Mol, A. 2008. The logic of care: health and the problem of patient choice. New York: Routledge.

Mol, A., I. Moser, and J. Pols. 2010. Care in practice: on tinkering in clinics, homes and farms. Bielefeld; Piscataway, NJ: Transcript Publishers.

Moore, D.S. 2005. Suffering for territory: race, place, and power in Zimbabwe. Durham: Duke University Press.

Mosse, D. 2005. Cultivating development: an ethnography of aid policy and practice. London: Pluto Press.

Nader, L. 1972. Up the anthropologist - perspectives gained from studying up. In Hymes, D. (ed.) Reinventing Anthropology. New York: Pantheon. Pp 284-311. draft 
Nittler, J., and H. Tschinkel. 2005. Community forest management in the Maya Biosphere Reserve of Guatemala: protection through profits. US Agency for International Development (USAID) and Sustainable Agriculture and Natural Resource Management (SANREM), University of Georgia, USA.

OMYC (Organización Manejo y Conservación de Uaxactún). 2009. Reseña historica. [Historical Overview.] Uaxactún, Petén, Guatemala.

Pacheco, P., D. Barry, P. Cronkleton, A. Larson and I. Monterroso. 2008. From agrarian to forest tenure reforms in Latin America: assessing their impacts for local people and forests. Presented to the conference of the International Association for the Study of the Commons (IASC).

Peluso, N. 1995. Whose woods are these? Counter-mapping forest territories in Kalimantan, Indonesia. Antipode 27(4): 383-388.

Ribot, J. C., and A. M. Larson. 2005. Democratic decentralization though a natural resource lens. New York: Routledge.

Salleh, A. 1993. Class, race, and gender discourse in the ecofeminism/deep ecology debate. Environmental Ethics 15(3): 225-244.

Schwartz, N.B. 1990. Forest society: a social history of Petén, Guatemala. Philadephia: University of Pennsylvania Press.

Sivaramakrishnan, K. 2000. Crafting the public sphere in the forests of West Bengal: democracy, development, and political action. American Ethnologist 27(2): 431-461.

Sundberg, J. 1998. NGO landscapes in the Maya Biosphere Reserve, Guatemala. Geographical Review 88(3): 388-412.

Tronto, J.C. 1993. Moral boundaries: a political argument for an ethic of care. New York: Routledge.

Tsing, A.L. 2005. Friction: an ethnography of global connection. Princeton: Princeton University Press.

Tsing, A.L. 2009. Supply chains and the human condition. Rethinking Marxism 21(2): 148-176.

West, P. 2006. Conservation is our government now: the politics of ecology in Papua New Guinea. Durham: Duke University Press.

Williams, F. 2001. In and beyond new Labour: towards a new political ethics of care. Critical Social Policy 21(4): 467-493.

Zerner, C. 1994. Through a green lens: the construction of customary environmental law and community in Indonesia’s Maluku Islands. Law and Society Review 28(5): 1079-1122.

Zetina Tún, J.F. 2011. Línea base para el monitoreo socio-económico: unidad de manejo "Uaxactún" [Baseline for social-ecological monitoring: management unit "Uaxactún"]. Uaxactún, Petén, Guatemala: Wildlife Conservation Society/OMYC-Uaxactún. 